International Journal of Instruction e-ISSN: 1308-1470 • www.e-iji.net

Article submission code: 20201230075416

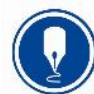

January $2022 \bullet$ Vol.15, No.1

p-ISSN: 1694-609X

pp. $135-152$

Received: 30/12/2020

Revision: 07/06/2021
Accepted: 04/07/2021

OnlineFirst: $17 / 10 / 2021$

\title{
Moodle-Based Online Learning Management in Higher Education
}

\section{Imam Makruf}

Institut Agama Islam Negeri Surakarta, Indonesia, imam.makruf@iain-surakarta.ac.id

\section{Andi Arif Rifa'i}

Institut Agama Islam Negeri Surakarta, Indonesia, andiarifrifai@iain-surakarta.ac.id

\section{Yunika Triana}

Institut Agama Islam Negeri Surakarta, Indonesia, yunika@iain-surakarta.ac.id

The COVID-19 pandemic gives a big impact on various aspects of human life, including higher education institutions. Institut Agama Islam Negeri (State Institute for Islamic Studies) Surakarta (IAIN Surakarta) as one of the Islamic higher education institutions in Indonesia has developed online learning management using Moodle platform. This study tries to measure the level of implementation of learning management in three dimensions of Moodle-based online learning; planning of learning, implementation of learning and evaluation. This study used a quantitative approach with a sample of 718 students from five faculties based on the descriptive analysis, report showed that planning of learning was in the high category with an average of 4.06 (in scale 5), the implementation of learning was in the medium category with an average of 3.35 and evaluation of learning was also in the medium category with an average of 3.14. It meant that it was necessary to optimize the implementation and evaluation of learning. While the results of CFA showed that the three manifest variables were below 0.4 , namely the use of Zoom, Google Meet or others (outside Moodle) for synchronous $(\lambda=0.01$, mean $=$ $3.86)$, the use of Google Classroom, WhatsApp or others for asynchronous $(\lambda=$ 0.04 , mean $=4.31)$, and the examination in the form of assignments $(\lambda=0.11$, mean $=3.86)$. So, it can be concluded that the use of e-learning based Moodle has less optimal in implementation and evaluation of learning. Therefore, it is necessary to improve the quality of applications, supporting facilities and user capabilities.

Keywords: moodle-based learning, planning of learning, implementation of learning, evaluation of learning, higher education

\section{INTRODUCTION}

Online learning in higher education like university during the Covid-19 pandemic might probably reduce the quality of education in Indonesia. Recent research reports that under $50 \%$ of students in Indonesia are not ready for online learning because of various

Citation: Makruf, I., Rifa'i, A. A., \& Triana, Y. (2022). Moodle-based online learning management in higher education. International Journal of Instruction, 15(1), 135-152. https://doi.org/10.29333/iji.2022.1518a 
aspects (Giatman et al., 2020). One condition is caused by the readiness of the university, which has been conducting offline learning, must change or switch to an online mode. This new shift gives also new problems because of the inadequacy of infrastructure, human resources, and e-learning applications for the implementation of full online lectures. Although higher education institutions generally have information technology infrastructure for academic services and learning, they cannot support the implementation of full online learning, which basically require adequate servers, a stable internet network, and integration of e-learning application systems with existing academic service systems. This does not only happen in Indonesia, but in other countries such as in Romania, Philippine and other countries (Radu et al., 2020), (Joaquin et al., 2020). In addition, aspects of human resources such as academic and IT staff and lecturers have not get ready to carry out services or online learning processes. Lecturers and staff have not had the skills or abilities to use IT technology for online classroom management because they used to undertake traditional learning (Zainal Ilmi et al, 2020).

The concept of on-line learning during the Covid-19 pandemic can currently be used by education providers as a solution to improve face-to-face lectures which have had weaknesses including limited duration, weak facilities in classrooms and weak flexibility in learning process. Such technologies are expected to provide ease of learning for students and also lecturers. Today's technologies combine asynchronous and synchronous learning experiences (Keren-kolb, 2013). Asynchronous provides material, instruction and course, and synchronous provides interactive communication to give positive reinforcement to students at home using digital media (Mantasiah, 2021). Therefore, such services can improve the quality and efficiency of learning and teaching process in the university (Mlotshwa et al., 2020). In other words, the on-line learning should not reduce the criteria for face-to-face learning, and if it is managed properly, it will add to the positive side of face-to-face lectures. Moodle-based online learning is one of many online platforms that offer synchronous and asynchronous modes with following tips.

\section{Management of Moodle-Based Online Learning}

Moodle-based online learning management has long been used as a support for classroom learning. In its history, the development of Moodle was started in 1999 by Martin Dougiamas, who worked as a WebCT administrator at Curtin University of Technology (Kats, 2010). This platform has complete features, flexible, and widely used by universities in various countries. It was claimed that Moodle has been used by more than 30,000 educational institutions in the world (Cole \& Foster, 2007) such as in Hong Kong and other countries in Asia (Luk et al., 2018). The choice of Moodle as an online learning platform is based on its ability to create great, flexible and engaging learning experiences. Moreover, Moodle is a free open source learning management platform that makes it very attractive to users (Nash \& Rice, 2018). Moodle-based online lecture management uses following basic dimensions of the management system same as faceto-face teaching. 


\section{Planning of Moodle-based online learning}

Planning on the Moodle-based online learning system is an initial process of its use with stages including; creating e-learning accounts, determining course activities, time schedules and so on. This step requires extra time where a teacher must determine what material and methods will be used in learning (Nash \& Rice, 2018). This strategy is an important effort to make class activities visible in e-learning. In asynchronous learning, for example, video clips, PDF documents and any other open educational resources are usually prepared earlier (Nichols, 2016). Moreover, lecturers can provide Massive Open Online Course (MOOC) to design new teaching strategies, methods and techniques in the platform (Aljaraideh, 2019). So, lecturers can bring informal ways of learning into formal setting.

E-learning is one way to integrate student learning needs with technology (De Clunie et al., 2013). It was also explained that in the learning management system, planning needs to pay attention to performance expectancy, effort expectancy, social influences and facilities (Ramllah \& Nurkhin, 2020). These expectancies are made in a structured schedule design that regulates the learning sequence, learning methods and learning materials. Thus, the students will be ready to follow lesson in every meeting. Based on this concept, Moodle-based learning planning can be measured through the following aspects; 1) uploading the learning plan of semester on Moodle facilities, 2) explaining the learning plan of semester at the beginning of the semester, 3) making a learning contract between lecturer and students and 4) uploading the learning contract on Moodle facilities.

\section{Implementation of Moodle-based online learning}

Moodle-based online learning is the same as face-to-face learning which also expects active and effective learning. This mode allows synchronous and asynchronous use of the learning support system provided by the campus (Chourishi, 2015). With this system the use of e-learning, such as students can study anywhere and anytime without having to come to class. Several previous studies reported that e-learning ability can increase learning effectiveness(Goyal \& Tambe, 2015). Other studies have specifically found that Moodle-based learning management systems make it easier for students to adapt to learning technology (Umek, Keržič, et al., 2015). In addition, e-learning can significantly increase teacher and student creativity (Gunawan et al., 2019).

Besides having a positive impact, Moodle-based online learning was also found to be ineffective in this learning which was caused by a lack of interaction between students and lecturers. This interaction problem can actually be minimized by connecting the social interaction between lecturers and students with a technological approach (Wood, 2010). This interactive model places a combination of synchronous and asynchronous simultaneously. In the flipped learning class, for example, students are in class at a predetermined hour, and then the lecturer gives explanation directly. Lecturer directions will lure students to participate actively (Abar \& Carnevale de Moraes, 2019). Such 
model increases students' cognitive abilities to think creatively and communicate actively outside of the classroom (Algayres \& Triantafyllou, 2020).

Moodle platform can even bridge institutions to control directed learning policies. The quality of the implementation of learning can be reviewed by the institutional coordinator (the person in charge of the program), whether the rules have been implemented by the users or not (Umek, Aristovnik, et al., 2015). This system also allows to regularly see the presence of lecturers and students in lectures. This control is needed to monitor the quality of the learning pedagogy and to determine future technology development and learning management systems. Based on this concept, the implementation of Moodle-based learning can be measured through the following aspects; 1) Setting attendance, 2) Utilizing of Bigblue for synchronous, 3) Utilizing Zoom, Google meet, or others for synchronous activity, 4) Utilizing of e-learning for asynchronous activity, 5) Utilizing of Google classroom, WhatsApp (WA), for asynchronous activity 6) Making assignment and delivery of assignments using Moodle facilities, 7) Uploading teaching materials (PDF, PPT, Documents, Videos, etc.) on elearning and 8) Linking teaching materials on Moodle facilities.

\section{Evaluation of Moodle-based online learning}

Evaluation is the process of obtaining data to determine whether students can achieve goals according to the determined learning. This process should be able to measure student performance and provides steps to give feedback (Koneru, 2017). This evaluation management system does not only assess and mark students, but it is expected to be able to assess whether the learning method can improve student competence or not. Moodle-based learning management system offers various final assessment modes such as assignments, choice modules, forums and others. Recent data states that such evaluation by e-learning is rarely done by lecturers, because they are more likely to use e-learning for the needs of delivering material (Deepak, 2017). The ideal evaluation should be able to show indicators of student skills and learning quality.

From the explanation above, e-learning is expected to improve the three dimensions of face-to-face lectures without reducing the basic concepts of ideal learning in general. Basically, e-learning courses only replace approach (conventional to digital media), not replace the basic principles of learning. Based on this concept, Moodle-based learning evaluation can be measured through the following aspects; 1) using Moodle facilities, 2) given by the lecturer in the form of assignments and 3) using Moodle facilities for submitting assignment.

\section{Implementation of Learning Management System Using Moodle}

Several research results indicated the use of various applications of e-learning (Samudi et al., 2020). La Consolacion University Philippines developed a web-based classroom named Eliademy, this platform besides having benefits in learning management, also has its own challenges, especially regarding the need for a strong internet connection (Francisco \& Barcelona, 2020). There are many learning management platforms in use around the world, among which the ones that are also popular are the use of the Moodle and ALTO platforms (Kats, 2010). The naming of the Moodle application for online 
learning appears varies in several universities. For example, the University of Indonesia named it with Student Centered e-Learning Environment (SCELE) (Santoso et al., 2018), Universiti Sains Islam Malaysia (USIM) used Online Distance Learning (ODL) (Zainuddin et al., 2016), IAIN Surakarta has developed SiKulon (Sistem Kuliah OnLine/ online learning system) at https://elearning.iain-surakarta.ac.id and many others.

The use of a learning platform is a central point in determining the success of online learning. Based on the recent research (Rakic et al., 2020), he found that there was a significant correlation between the abilities of students and the platform used. In addition to the ability, other research showed positive progress from students (Chung \& Ackerman, 2015). The learning impact was different in the level of education (Miller et al., 2020). Higher education is the institution that gets the biggest positive impact compared to other education levels. However, in practice in higher education, it was found that many lecturers had not optimally utilized Moodle in various learning activities (Ghilay, 2013). Under these conditions, evaluation of implementing online learning is very important in order to improve the quality of the learning process and output during the pandemic and post covid-19 recovery.

During the Covid-19 pandemic, learning management system in IAIN Surakarta has developed Moodle-based online learning to increase the effectiveness of online learning management. In line with the philosophy of this platform, Moodle is designed to support the creation of interactive learning styles. This concept is supported by the philosophy of social construction which believes that people learn best when they interact with learning material, build new material for others, and interact with other students about the material (Nash \& Rice, 2018). Based on the recent research, learning management system using Moodle was perceived to be web-based flexible learning that offer interactive learning similar to traditional learning (Coman et al., 2020). Therefore, researcher tries to find the effectiveness of using Moodle developed by IAIN Surakarta by assessing the use of features on Moodle.

Based on preliminary research, it was found that some lecturers gave negative and positive responses to the use of Moodle in learning management during a pandemic. Some lecturers were not familiar and need a different time in mastering Moodle-based learning management (SiKulon). During the Covid 19 pandemic, which prompted a social distancing policy from the government, socialization of SiKulon to both lecturers and students was carried out online with various limitations. Support capacity, such as infrastructure, stability of the internet network in each region, as well as technological literacy from students and lecturers were critical aspects of implementing Moodle-based learning management.

\section{METHOD}

\section{Design, Data Collection Techniques and Analysis of Research}

This research was conducted with a quantitative approach or quantitative research in the form of an online survey (Stephen Gorard, 2001) (Creswell, 2012). As a quantitative research, this study uses objective measurements to collect numerical data that is used to answer predetermined questions (Ary et al., 2010). The form of the instrument used in 
this study was a questionnaire. This research data collection using a questionnaire by utilizing google form facilities. The questionnaire was distributed to students through the student and faculty WhatsApp group. Only questionnaires that received a perfect response were included in the data analysis.

Data analysis in this study used descriptive techniques and CFA (Confirmatory Factor Analysis) using SEM AMOS (Byrne, 2010). Descriptive techniques are intended to describe student responses in the form of mean answers and standard deviation. Meanwhile, the CFA analysis in this study is intended to describe which factor (indicator) is the strongest and weakest in each dimension.

\section{Research Sample}

The research was conducted at IAIN Surakarta with a population of 15.824 students (based on data on pddikti.kemdikbud.go.id on October 30, 2020). Samples were determined randomly by distributing questionnaires in the form of google forms to students via the WhatsApp group at each faculty. The questionnaires were distributed between $20^{\text {th }}$ until $30^{\text {th }}$ October 2020 . There are 822 respondents and then eliminated respondent out of the criteria's including only respondents who are in semesters $3-7$, they are taking online lectures with SiKulon, and filling out the latest form on October $30^{\text {th }}, 2020$. From the results of data elimination, a sample of 718 students was obtained or as much as $4.5 \%$ of the population spread over 5 (five) faculties with details as in tables 1 and 2 below:

Table 1

Distribution of respondent

\begin{tabular}{lll}
\hline Faculty & Frequency & Percent \\
\hline Faculty of Adab and Language (FAB) & 114 & 15.88 \\
\hline Faculty of Syari'ah Law (FASYA) & 244 & 33.98 \\
\hline Faculty of Economy and Islamic Business (FEBI) & 104 & 14.48 \\
\hline Faculty of Science Education (FIT) & 135 & 18.80 \\
\hline Faculty of Ushuludin and Da'wah (FUD) & 121 & 16.85 \\
\hline Total & 718 & 100.00 \\
\hline Semester & Frequency & Percent \\
\hline 3 (three) & 177 & 24.70 \\
\hline 5 (five) & 464 & 64.60 \\
\hline 7 (seven) & 77 & 10.70 \\
\hline Total & 718 & 100.00 \\
\hline
\end{tabular}

Respondents in the study came from five faculties with 718 total students (respondents). The distribution of respondent data based on faculty is FAB $15.9 \%$ (114 students), FASYA 34\% (244 students), FEBI 14.5\% (104 students), FIT 18.8\% (135 students) and FUD $16.9 \%$ (121 students). So, it can be concluded that the respondents in this study were evenly distributed across all faculties and the highest response came from the Syari'ah Faculty (FASYA). While the distribution of respondents based on the semester, the highest came from the fifth semester students $(64.50 \%)$ followed by the third semester $(24.70 \%)$ and the least came from the seventh semester $(10.70 \%)$. The distribution based on faculty can be seen in table 2 below: 
Table 2

Respondents by faculty and semester

\begin{tabular}{lcccccccc}
\hline & \multicolumn{2}{c}{ Semester 3 } & \multicolumn{2}{c}{ Semester 5 } & \multicolumn{2}{c}{ Semester 7 } & \multicolumn{2}{c}{ Total } \\
\hline Faculty & F & P & F & P & F & P & F & P \\
\hline Faculty of Adab and Language (FAB) & 45 & $25 \%$ & 64 & $14 \%$ & 5 & $6 \%$ & 114 & $16 \%$ \\
\hline Faculty of Syari'ah Law (FASYA) & 63 & $36 \%$ & 157 & $34 \%$ & 24 & $31 \%$ & 244 & $34 \%$ \\
\hline $\begin{array}{l}\text { Faculty of Economy and Islamic Business } \\
\text { (FEBI) }\end{array}$ & 27 & $15 \%$ & 53 & $11 \%$ & 24 & $31 \%$ & 104 & $14 \%$ \\
\hline Faculty of Science Education (FIT) & 18 & $10 \%$ & 96 & $21 \%$ & 21 & $27 \%$ & 135 & $19 \%$ \\
\hline Faculty of Ushuludin and Da'wah (FUD) & 24 & $14 \%$ & 94 & $20 \%$ & 3 & $4 \%$ & 121 & $17 \%$ \\
\hline Total & 177 & $25 \%$ & 464 & $65 \%$ & 77 & $11 \%$ & 718 & $100 \%$ \\
\hline
\end{tabular}

Based on table 2 above, it can be concluded that the most respondents from all existing faculties came from $5^{\text {th }}$ semester students in the following order; FASYA (157 or 34\%), FIT (96 or $21 \%$ ), FUD (94 or $20 \%)$, FAB (64 or 14\%), FEBI (53 or $11 \%)$. The lowest response from each faculty came from $7^{\text {th }}$ semester students except for the Faculty of Science Education (FIT), the lowest response came from $3^{\text {th }}$ semester students with 18 respondents.

\section{Research Instruments}

In compiling the research instrument, researcher used the following steps: identifiying the variables in the title formulation, describing these variables into sub-variables, looking for indicators in the sub-variables, listing descriptors of each indicator, formulating each descriptor into instrument items, complete the instrument with filling instructions and a preface (Riduwan, 2003). This study uses an instrument developed by combining the concept of learning management with Moodle technology (Kats, 2010)(Bach et al., 2007). In learning, there are three main dimensions, namely learning planning, learning implementation and learning evaluation. Learning planning includes; submission of learning plan, explanation of learning plan, Preparation and submission of learning contracts. Learning implementation includes; recording attendance, synchronous and asynchronous explanation of material, assignments, and delivery of teaching materials and learning resources. While the learning evaluation includes; conducting and submitting exams, tests or assignments. This research instrument uses a Likert scale with 5 answer categories (Strongly Agree, Agree, Doubt, Disagree, Strongly Disagree).

\section{FINDINGS AND DISCUSSION}

Moodle-based online learning management at IAIN Surakarta was reviewed in three main dimensions, namely planning of learning, implementation of learning and evaluation of learning. The results of respondent are studied using following review:

\section{Planning of Learning}

Moodle-based online learning planning is measured by four criterias, namely; uploading the learning plan of semester on SiKulon, explaining the learning plan of semester at the beginning of the semester, making a learning contract between lecturer and students, and uploading the learning contract on SiKulon. An overview on SiKulon of the responses from students can be seen in table 3 below: 
Table 3

Planning of learning

\begin{tabular}{|c|c|c|c|}
\hline Dimension & Criteria & Average (SD) & Category \\
\hline \multirow[t]{5}{*}{$\begin{array}{l}\text { Planning of } \\
\text { Learning }\end{array}$} & $\begin{array}{l}\text { uploading the learning plan of semester on Moodle facilities } \\
\text { (X1) }\end{array}$ & $3.58(0,996)$ & High \\
\hline & $\begin{array}{l}\text { explaining the learning plan of semester at the beginning of the } \\
\text { semester (X2) }\end{array}$ & $4.17(0,981)$ & High \\
\hline & making a learning contract between lecturer and students (X3) & $4.35(0,886)$ & High \\
\hline & uploading the learning contract on Moodle facilities (X4) & $4.16(0,951)$ & High \\
\hline & Total & 4.07 & High \\
\hline
\end{tabular}

Based on table 3 above, it can be concluded that the learning planning carried out by the lecturer using an online learning system through e-learning is in the high category (average response is 4.07 on a scale of 5). The willingness of lecturers to upload learning plan on e-learning received the lowest response compared to the other three criteria, with an average rating of 3.58 (Standard Deviation $(S D)=0.886$ ). Based on the standard deviation, it can be concluded that there is no SD that exceeds the average. It means that the data is in the good category and is not biased.

\section{Implementation of Learning}

The implementation of learning is a form of action from planning that has been prepared in a comprehensive manner in learning plan format. In describing how learning planning is implemented in Moodle-based teaching and learning activities, it is described by criteria or characteristics including: the use of e-learning for student presence, the use of Bigblue for face-to-face lectures (synchronous), the use of applications outside of elearning such as Zoom, Google meet, or others for Synchronous mode by lecturers, the use of e-learning to support asynchronous learning, use of Google classroom, WhatsApp or other applications for asynchronous and sending student assignments, using elearning to upload teaching materials, and using e-learning to linking teaching materials. The average students' response to the criteria for implementing Moodle-based learning is explained in following statements:

Table 4

Implementation of learning

\begin{tabular}{llll}
\hline Dimension & Criteria & Average (SD) & Category \\
\hline $\begin{array}{l}\text { Implementation } \\
\text { of learning }\end{array}$ & Setting attendance (X5) & $3.53(0,974)$ & High \\
\cline { 2 - 4 } & Utilizing of bigblue for synchronous (X6) & $2.13(1,077)$ & Low \\
\cline { 2 - 4 } & $\begin{array}{l}\text { Utilizing Zoom, Google meet, or others for synchronous } \\
\text { activity (X7) }\end{array}$ & $3.86(0,895)$ & High \\
\cline { 2 - 4 } & Utilizing of e-learning for asynchronous activity(X8) & $3.25(1,076)$ & Moderate \\
\cline { 2 - 4 } & $\begin{array}{l}\text { Utilizing of Google classroom, WhatsApp (WA), for } \\
\text { asynchronous activity (X9) }\end{array}$ & $4.31(0,681)$ & High \\
\hline & $\begin{array}{l}\text { Making assignment and delivery of assignments using } \\
\text { Moodle facilities (X10) }\end{array}$ & $3.18(1,013)$ & Moderate \\
\cline { 2 - 4 } & $\begin{array}{l}\text { Uploading teaching materials (PDF, PPT, Documents, } \\
\text { Videos, etc.) on e-learning (X11) }\end{array}$ & $3.58(1,024)$ & High \\
\cline { 2 - 4 } & Linking teaching materials on Moodle facilities (X12) & $2.98(1,085)$ & Moderate \\
\hline & Total & 3.35 & Moderate \\
\hline
\end{tabular}


From the eight indicators above, the total average respondent's answer is 3.35 , meaning that the implementation of learning is in the moderate category. With the following description:

a. Based on the standard deviation, it can be concluded that there is no SD that exceeds the average, meaning that the data distribution is in the good (normal) and unbiased categories.

b. The use of presence through e-learning by lecturers in the high category with an average of 3.53 respondents' answers.

c. The use of Bigblue by lecturers in supporting synchronous lectures is still low (the average respondent's answer is 2.13 .

d. The use of synchronous activity using zoom, google meet, or others are in the high category with an average of 3.86 .

e. The use of asynchronous learning is carried out by lecturers in e-learning SiKulon (in the form of discussion or other) in the medium category, with an average of 3.25

f. The use synchronous learning using WhatsApp, Google Classroom, or others are in the high category, with an average of 4.31

g. The use of assignments and assignments using e-learning is in the medium category (average 3.18)

h. Uploading teaching materials in e-learning in the form of PDF, PPT, Documents, Audio, Video or other is in the high category, with an average of 3.58

i. Linking teaching materials on SiKulon is in the medium category, with an average of 2.98

Based on the result above, it can be concluded that video conferencing applications such as Zoom, Google Meet or others are more preferred by lecturers to Bigblue button, which is available in e-learning with an average ratio of 3.86> 2.13. Likewise, Google Classroom, WhatsApp or others are preferred by lecturers to e-learning with an average ratio of 4.31> 3.25. The use of e-learning by the lecturer to provide an explanation of the material by uploading on a YouTube linked on the e-learning model has not been optimal (response is in the medium category).

\section{Evaluation of Learning}

Learning evaluation is an activity to measure the achievement of the planned learning objectives. The results of this evaluation will show the level of effectiveness in achieving learning objectives. Learning evaluation using Moodle-based learning applications is seen from three criteria, namely; examination Moodle facilities according to a set schedule, lecturers gives assignments to assess learning outcomes, and lecturers use e-learning to collect students' works. The description of the average respondents' answers is as shown in table 5 below:

Table 5

Evaluation of learning

\begin{tabular}{clll}
\hline Dimension & Criteria & Average (SD) & Category \\
\hline \multirow{2}{*}{$\begin{array}{l}\text { Evaluation } \\
\text { of learning }\end{array}$} & Using Moodle facilities for examination (X13) & $2.66(1.202)$ & Moderate \\
\cline { 2 - 4 } & Giving assignments (X14) & $3.78(1.014)$ & High \\
\cline { 2 - 4 } & Using Moodle facilities for submitting assignments (X15) & $2.97(1.142)$ & Moderate \\
\hline & Total & 3.14 & Moderate \\
\hline
\end{tabular}


Based on table 5 above, it can be concluded that;

a. Based on the value of the standard deviation, it can be concluded that there is no SD that exceeds the average. It means that the data distribution is in the good and unbiased category.

b. Examination using Moodle platform by lecturers according to schedule is in the medium category, with an average of 2.66. This means that the lecturer has not carried out an exam or evaluation in accordance with the academic calendar set by the university.

c. Giving the examination in the form of assignments is in high category, with an average of 3.78. This means that most lecturers prefer to use this evaluation rather than the others.

d. Assignment collection using e-learning is in medium category, the average is 2.97. This means that lecturers have not used the existing Moodle facilities to collect students' works.

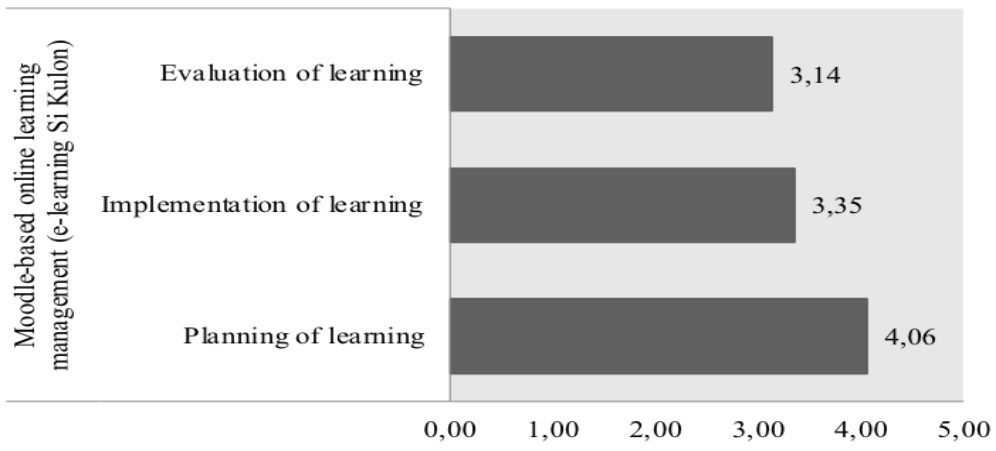

Figure 1

Description of moodle-based online learning management

Descriptive analysis of Moodle-based online learning management in three main dimensions, namely planning of learning, implementation of learning and evaluation of learning above (see figure 1), shows that planning of learning using Moodle is stated in the dimension with the highest average response compared to the other two dimensions. It is reported with value 4.07 on a scale of 5 . It can be concluded that the learning management in the dimensions of implementation and evaluation of learning are in the moderate category. In other words, these two dimensions are not optimally used.

\section{Analysis of Factors in Moodle-Based Online Learning Management}

Although the average-based descriptive analysis above has provided an overview of Moodle-based online learning management, it needs further analysis using CFA (Confirmatory Factor Analysis) to find out which indicators or aspects are dominant (high) and which are low. based on the factor weight coefficient. The factor weight coefficient basically shows the closeness of the relationship or correlation between the 
latent variable and the manifest variable (Bachrudin \& Tobing, 2003). The minimum limit of factor weight coefficient (lambda- $\lambda$ ) can be considered feasible not less than 0.4 .

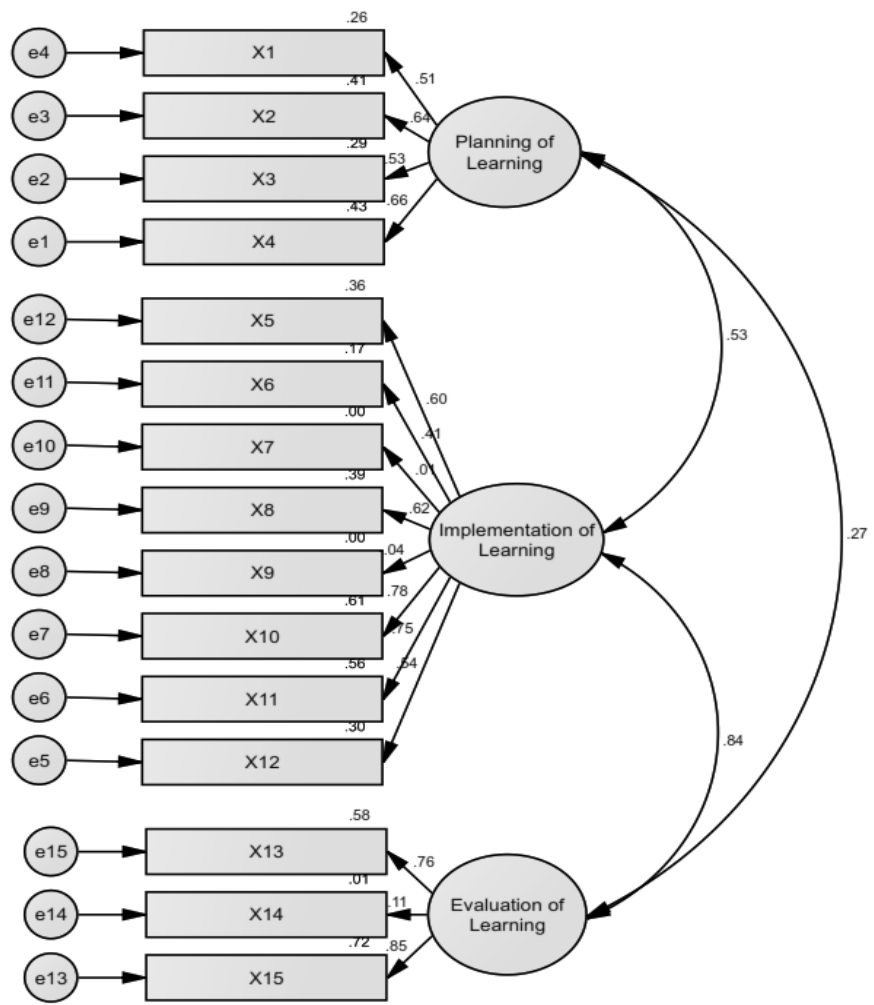

Figure 2

Confirmatory factor analysis (CFA) moodle-based online learning management

Figure 2 shows that the manifest variable (observed factor or indicator) of the latent variable (dimension) of Moodle-based learning management, namely planning, implementing and evaluating (regression weigh) below 0.4 is the indicator number X9, $\mathrm{X} 7$, and X14. This means that the use of Zoom, Google meet, or others for synchronous (X7), the use of Google classrooms, WhatsApp, for asynchronous (X9), and examinations given by lecturers in the form of assignments (X14) cannot explain Moodle-based learning management or it can be said not part of from the indicator or variable manifest. It can be concluded that of the five observed factors (manifest variables) of the learning planning dimensions all have a loading factor weight of above 0.4. It means that all indicators can explain the planning dimensions significantly and the highest indicator is $\mathrm{X} 4$ (uploading learning contracts on page of SiKulon). 


\begin{tabular}{|lll|rrrrr|}
\hline & & & Estimate & S.E. & \multicolumn{1}{c|}{ C.R. } & P & Label \\
\hline X4 & $<--$ & PL & 1.000 & & & & \\
X3 & $<--$ & PL & .757 & .068 & 11.089 & $* * *$ & par_1 \\
X2 & $<---$ & PL & 1.011 & .083 & 12.238 & $* * *$ & par_2 \\
X1 & $<--$ & PL & .812 & .104 & 7.791 & $* * *$ & par_3 \\
X12 & $<---$ & IL & 1.000 & & & & \\
X11 & $<--$ & IL & 1.295 & .094 & 13.835 & $* * *$ & par_4 \\
X10 & $<---$ & IL & 1.337 & .097 & 13.816 & $* * *$ & par_5 \\
X9 & $<---$ & IL & -.048 & .047 & -1.025 & .305 & par_6 \\
X8 & $<---$ & IL & 1.137 & .091 & 12.460 & $* * *$ & par_7 \\
X7 & $<---$ & IL & .009 & .061 & .141 & .888 & par_8 \\
X6 & $<---$ & IL & .746 & .082 & 9.140 & $* * *$ & par_9 \\
X5 & $<---$ & IL & .992 & .082 & 12.039 & $* * *$ & par_10 \\
X15 & $<--$ & EL & 1.000 & & & & \\
X14 & $<---$ & EL & .111 & .043 & 2.590 & .010 & par_11 \\
X13 & $<---$ & EL & .939 & .049 & 19.276 & $* * *$ & par_12 \\
\hline
\end{tabular}

Figure 3

Regression weights

In the dimensions of learning implementation (EL) there are two indicators whose loading factor weight $(\lambda)$ is below 0.4, namely the use of Zoom, Google meet, or others for Synchronous (X7) with P-Value $=0.888$ (see figure 3.), utilization Google classroom, WA, for asynchronous (X9) with P-Value $=0.305$. These two manifest variables have an average of $\mathrm{X} 7=3.86$ and an average of $\mathrm{X} 9=4.31$. It means that the lecturers used other applications instead of using Bigblue which has been provided in SiKulon's e-learning. They tend to use other applications such as Google Classroom, WhatsApp or others to support learning implementation.

In the dimension of learning evaluation (EL) in the form of assignments (X14) it has a loading factor weight of $0.11(\mathrm{P}-$ Value $=0.305)$ with an average of 3.78. It means that this indicator unable to explain dimension of learning evaluation. The indicator of collecting students' works using SiKulon e-learning (X13) are on average of 2.66. It can be concluded that the assignments carried out by lecturers are not all collected using elearning.

Based on research findings, it can be concluded that the existing Moodle-based learning management is less than optimal, especially in the dimensions of implementation and evaluation of learning. Ideal implementation of learning management system is determined by the availability of technical infrastructure, reliable physical installations, bandwidth, management system, and academic staff' and lectures' capability (Kats, 
2010). The use of synchronous learning using external platform like zoom, google meet and other is bigger than the use of internal feature. It is caused the limited use of Bigblue Button. Therefore, the capacity of this system is a crucial factor in increasing its effectiveness of higher education operation. There must be advanced development on technical infrastructure of Moodle platform. Learning management system must provide reliable documentation, administration, tracking, reporting and automation (Naz \& Khan, 2018). It seems that the large use of external usage caused none of documentation, administration, tracking, reporting and automation.

It also shows that the weaknesses of Moodle-based learning management in two dimensions, namely implementation and evaluation of learning. In the same study related to the implementation of Moodle-based online learning by Miller and Edwards; It was found that lectures with Moodle were preferred by postgraduate students than undergraduate students as measured by the three dimensions of the framework Community of Inquiry $(\mathrm{CoI})$; that is, their online learning, perception, and technology delivery of their courses (Miller \& Edward, 2020). From the facilitator's point of view, in line with the research conducted by Richardson et al, it is also necessary to see how the short and long term perceptions of the use of Moodle-based learning (Richardson et al., 2012). Besides, students who use e-learning often experience interference with the computer devices and data access they use (Al-ani, 2013). Meanwhile, Dahal and Pangeni also explained the weaknesses of evaluation. It was stated that the facilitator did not realize or take advantage of the assessment features in Moodle, so that students lost this very useful self-assessment tool and peer for studying in higher education. So, the study recommends training for facilitators in designing, creating and utilizing existing assessment features (Dahal \& Pangeni, 2019). In line with theory of learning management system stated by (Naz \& Khan, 2018), documentation, administration, tracking, reporting and automation needs awareness and digital literacy from all parties. Institutions must provide easy and convenient access so that lecturers and students can use online classes comfortably. The role of institutions in providing massive information and wise policy to users will also increase digital literacy in the use of learning management systems.

Students' perceptions and attitudes towards e-learning are important factors for the success of the system (Hsu \& Chang, 2013). Another research was found that students perceive the quality of interaction positively (with themselves, with their lecturers (instructors) and content using Moodle-based learning. The study recommends that higher education institutions should continue to use Moodle and encourage lecturers to apply it in teaching by optimizing Moodle distinctive features (Abdelraheem, 2012). The perfect quality of educational process depends on many factors such as; digital literacy of students and lecturers, teaching strategies, interaction with students, relation between students and faculty, fast feedback, active learning, collaborative learning, technology application and many others (Coman et al., 2020). Moreover, the use of interactive tutorial videos in learning by embedding YouTube links on Moodle is a crucial factor, because it can increase student learning satisfaction (Nagy, 2018). So, it can be concluded that the use of e-learning based Moodle in higher education has less optimal in implementation and evaluation of learning. Therefore, the institution needs to 
improve the quality of applications, supporting facilities and user capabilities including students, academic staffs and lecturers.

\section{CONCLUSION}

The Covid-19 pandemic has brought new demands and cultures in learning management to universities around the world. Digital platform like online-based learning management becomes new hope. IAIN Surakarta developed the Moodle-based learning (SiKulon) to ensure the implementation and assurance of learning quality. Based on the research findings, it shows that online-based learning management is less optimal, especially in the dimensions of learning implementation and evaluation of learning. However, in planning of learning is included in the high or optimal use.

This study has found weaknesses in important dimensions of learning management system, namely; implementation and evaluation of learning. In the implementation of learning, there are still many lecturers who use other platforms outside Moodle, such as Zoom, Google Meet or others to perform synchronous learning (digital face-to-face learning) and Google Classroom, WhatsApp and others for synchronous learning. This selection can be caused by three main factors; system quality, supporting facilities and users' capability. In line with that, it is necessary to optimize the use of applications available in e-learning with a variety of adequate support capacities. Likewise, with the evaluation, the use of the menu in the Moodle-based learning application, especially on students' work collection, needs to be optimized both from the system and the users (students and lecturers). In addition, the utilization of the evaluation or assessment features needs to be improved by maximizing the functionality of the available systems. In line with the research, further studies are expected to evaluate technical problem that experienced by the students and the institutions specifically during online learning. The findings will reflect many aspects of education support. Results showed that online learning facilities, teaching method and role of government are playing important role. However, it requires precise parameters to conduct the research. Institution can conduct an in-depth survey as an internal evaluation step. Positive perceptions of users reflect expectancy of users, but institutions also need to see performance expectancy, effort expectancy, social influences and facilities. The results will determine what the institution must do to develop the learning service.

\section{REFERENCES}

Abar, C. A. A. P., \& Carnevale de Moraes, U. (2019). Flipped classrooms and moodle: Digital technologies to support teaching and learning mathematics. Acta Didactica Napocensia, 12(2), 209-216. https://doi.org/10.24193/adn.12.2.16

Abdelraheem, A. Y. (2012). Interactions quality in moodle as perceived by learners and its relation with some variables. Turkish Online Journal of Distance Education, 13(3), 375-389. https://doi.org/10.17718/tojde.30315

Al-ani, W. T. (2013). Blended learning approach using moodle and student' s achievement at sultan qaboos university in oman. Journal of Education and Learning, 2(3). https://doi.org/10.5539/jel.v2n3p96 
Algayres, M., \& Triantafyllou, E. (2020). Learning analytics in flipped classrooms: A scoping review. Electronic Journal of E-Learning, 18(5), 397-409. https://doi.org/10.34190/JEL.18.5.003

Aljaraideh, Y. (2019). Massive open online learning (MOOC) benefits and challenges: A case study in Jordanian context. International Journal of Instruction, 12(4), 65-78. https://doi.org/10.29333/iji.2019.1245a

Ary, D., Jacobs, L. C., \& Sorensen, C. K. (2010). Introduction to research in education (Eighth). Wadsworth.

Bach, S., Haynes, P., \& Lewis, J. (2007). Online learning and teaching in higher education. Open University Press.

Bachrudin, A., \& Tobing, H. L. (2003). Analisis data untuk penelitian survey dengan menggunakan lisrel 8. FMIPA UNPAD. Bandung.

Byrne, B. M. (2010). Structural equation modeling with AMOS: BHasic Concept, Applications, and Programming (Second). Routledge Taylor \& Francis Group.

Chourishi, D. (2015). Effective e-learning through moodle moodle for e-learning. International Journal of Advance Technology \& Engineering Research, 1(1), 34-38.

Chung, C., \& Ackerman, D. (2015). Student reactions to classroom management technology: Learning styles and attitudes toward moodle. Journal of Education for Business, 90(4), 217-223. https://doi.org/10.1080/08832323.2015.1019818

Cole, J., \& Foster, H. (2007). Using moodle: Teaching with the popular open source course management system. O'Reilly Community Press. https://doi.org/10.1017/CBO9781107415324.004

Coman, C., Țîru, L. G., Meseșan-Schmitz, L., Stanciu, C., \& Bularca, M. C. (2020). Online teaching and learning in higher education during the coronavirus pandemic: Students' perspective. Sustainability (Switzerland), 12(24), 1-22. https://doi.org/10.3390/su122410367

Creswell, J. W. (2012). Educational research: Planning, conducting, and evaluating quantitative and qualitative research. In Pearson (4th editio). Pearson Education (US).

Dahal, N., \& Pangeni, S. K. (2019). Workshopping in online courses: Insights for learning and assessment in higher education. International Journal of Multidisciplinary Perspectives in Higher Education, 4(1), 89-110.

De Clunie, G. T., Clifton, C. T., Castillo, A., \& Rangel, N. (2013). Android based mobile environment for moodle users. Proceedings of the IADIS International Conference Mobile Learning 2013, ML 2013, 125-132.

Deepak, K. C. (2017). Evaluation of moodle features at kajaani university of applied sciences-case study. In Procedia Computer Science (Vol. 116, pp. 121-128). https://doi.org/10.1016/j.procs.2017.10.021 
Francisco, C. D. C., \& Barcelona, M. C. (2020). Effectiveness of an online classroom for flexible learning. International Journal of Academic Multidisciplinary Research (IJAMR) ISSN:, 4(8), 100-107.

Ghilay, Y. (2013). Effectiveness of learning management systems in higher education. Journal of Online Higher Education, 3(2), 29-50.

Giatman, M., Siswati, S., \& Basri, I. Y. (2020). Online learning quality control in the pandemic covid-19 era in indonesia. Journal of Nonformal Education, 6(2), 168-175. https://journal.unnes.ac.id/nju/index.php/jne

Goyal, E., \& Tambe, S. (2015). Effectiveness of moodle-enabled blended learning in private indian business school teaching niche. The Online Journal of New Horizons in Education, 5(2), 14-22.

Gunawan, G., Sahidu, H., Susilawati, S., Harjono, A., \& Herayanti, L. (2019). Learning management system with moodle to enhance creativity of candidate physics teacher. Journal of Physics: Conference Series, 1417(1), 0-6. https://doi.org/10.1088/17426596/1417/1/012078

Hsu, H., \& Chang, Y. (2013). Extended TAM Model: Impacts of convenience on acceptance and use of moodle. US-China Education Review, 3(4), 211-218.

Joaquin, J. J. B., Biana, H. T., \& Dacela, M. A. (2020). The philippine higher education sector in the time of COVID-19. Frontiers in Education, 5. https://doi.org/10.3389/feduc.2020.576371

Kats, Y. (2010). Learning Management System Technologies and Software Solutions for Online Teaching: Tools and Applications. Information ScIence Reference.

Keren-kolb, B. L. (2013). Engage, Enhance, and Extend Learning. 5191(May), 20-27.

Koneru, I. (2017). Exploring moodle functionality for managing open distance learning e-assessments. Turkish Online Journal of Distance Education, 18(4), 129-141. https://doi.org/10.17718/tojde.340402

Luk, C.-H., Ng, K.-K., \& Lam, W.-M. (2018). The Acceptance of Using Open-Source Learning Platform (Moodle) for Learning in Hong Kong's Higher Education (pp. 249257). https://doi.org/10.1007/978-981-13-0008-0_23

Mantasiah, R. (2021). Assessing verbal positive reinforcement of teachers during school from home in the Covid-19 pandemic era. International Journal of Instruction, 14(2), 1037-1050.

Miller, T., \& Edward, P. (2020). Online learning: Practices, perceptions , and technology. Canadian Journal of Learning and Technology / La Revue Canadienne de l'apprentissage et de La Technologie, 46(1), 1-27.

Miller, T., MacLaren, K., \& Xu, H. (2020). Online learning: Practices, perceptions, and technology. Canadian Journal of Learning and Technology / La Revue Canadienne de l'apprentissage et de La Technologie, 46(1). https://doi.org/10.21432/cjlt27894 
Mlotshwa, N., Tunjera, N., \& Chigona, A. (2020). Integration of moodle into the classroom for better conceptual understanding of functions in mathematics. South African Journal of Education, 40(3), 1-14. https://doi.org/10.15700/saje.v40n3a1570

Nagy, J. T. (2018). Evaluation of online video usage and learning satisfaction: An extension of the technology acceptance model. International Review of Research in Open and Distributed Learning, 19(1).

Nash, S. S., \& Rice, W. (2018). Moodle 3 E-Learning Course Development (Fourth Edi). Packt Publishing.

Naz, T., \& Khan, M. (2018). Functionality gaps in the design of learning management systems. International Journal of Advanced Computer Science and Applications, 9(11), 371-374. https://doi.org/10.14569/ijacsa.2018.091152

Nichols, M. (2016). A Comparison of two online learning systems. Journal of Open, Flexible and Distance Education, 20(1), 19-32. http://www.jofdl.nz/index.php/JOFDL/article/view/257

Radu, M.-C., Schnakovszky, C., Herghelegiu, E., Ciubotariu, V.-A., \& Cristea, I. (2020). The Impact of the COVID-19 pandemic on the quality of educational process: A student survey. International Journal of Environmental Research and Public Health, 17(21), 7770. https://doi.org/10.3390/ijerph17217770

Rakic, S., Tasic, N., Marjanovic, U., Softic, S., Lüftenegger, E., \& Turcin, I. (2020). Student performance on an e-learning platform: Mixed method approach. International Journal of Emerging Technologies in Learning (IJET), 15(02), 187. https://doi.org/10.3991/ijet.v15i02.11646

Ramllah, R., \& Nurkhin, A. (2020). Analysis of factors affecting behavioral intention to use e-learning uses the unified theory of acceptance and use of technology approach. KnE Social Sciences, 2020, 1005-1025. https://doi.org/10.18502/kss.v4i6.6658

Richardson, J., Finholt-Daniel, M., Sales, G., \& Flora, K. (2012). Shifting pedagogical space: Egyptian educators use of moodle. International Journal of Education and Development Using Information and Communication Technology (IJEDCT), 8(2), 92106.

Riduwan. (2003). Skala Pengukuran Variabel-Variabel Penelitian. Alfabeta.

Samudi, S., Widodo, S., \& Brawijaya, H. (2020). The K-Medoids clustering method for learning applications during the COVID-19 pandemic. SinkrOn, 5(1), 116. https://doi.org/10.33395/sinkron.v5i1.10649

Santoso, H. B., Batuparan, A. K., Isal, R. Y. K., \& Goodridge, W. H. (2018). The development of a learning dashboard for lecturers : A case study on a student- centered e-learning environment. Journal Of Educators Online, 1, 1-14.

Stephen Gorard. (2001). Quantitative Methods in Educational Research: The Role of Numbers Made Easy (Vol. 110, Issue 9). Continuum. 
Umek, L., Aristovnik, A., Tomaževič, N., \& Keržič, D. (2015). Analysis of selected aspects of students performance and satisfaction in a moodle-based e-learning system environment. Eurasia Journal of Mathematics, Science and Technology Education, 11(6), 1495-1505. https://doi.org/10.12973/eurasia.2015.1408a

Umek, L., Keržič, D., Tomaževič, N., \& Aristovnik, A. (2015). Moodle e-learning system and students' performance in higher education: The case of public administration programmes. Proceedings of the International Conference on E-Learning 2015, ELEARNING 2015 - Part of the Multi Conference on Computer Science and Information Systems 2015, 97-104.

Wood, S. L. (2010). Technology for teaching and learning: Moodle as a tool for higher education. International Journal of Teaching and Learning in Higher Education Http://Www.Isetl.Org/Ijtlhe/ 2010, 22(3), 299-307.

Zainal Ilmi et al. (2020). Independence in learning, education management, and industry 4.0: Habitat Indonesia during COVID-19. Journal of Anthropology of Sport and Physical Education, 4(4), 63-66.

Zainuddin, N., Idrus, R., \& Jamal, A. F. M. (2016). Moodle as an ODL teaching tool : A perspective of students and academics. The Electronic Journal of E-Learning, 14(4), 282-290. 